\title{
Edukasi Jelantah sebagai Sumber Energi pada Kelompok Ibu Rumah Tangga di Desa Petir, Bogor
}

\section{(Education of Used Cooking Oil as an Energy source for the Housewives in Petir Village, Bogor)}

\author{
Dyah Wulandani ${ }^{*}$, Leopold Oscar Nelwan ${ }^{1}$, Dwi Setyaningsih ${ }^{2}$ \\ ${ }^{1}$ Departemen Teknik Mesin dan Biosistem, Fakultas Teknologi Pertanian, Institut Pertanian Bogor, \\ Kampus IPB Dramaga, Bogor 16680. \\ 2 Departemen Teknologi Industri Pertanian, Fakultas Teknologi Pertanian, Institut Pertanian Bogor, \\ Kampus IPB Dramaga, Bogor 16680. \\ *Penulis Korespondensi: dyahwu@apps.ipb.ac.id \\ Diterima November 2020/Disetujui Juni 2021
}

\begin{abstract}
ABSTRAK
Jelantah adalah minyak goreng bekas. Setelah dipakai lebih dari tiga kali untuk menggoreng, jelantah akan mengalami oksidasi dan membentuk senyawa radikal bebas yang berbahaya. Bila dikonsumsi dalam jumlah tertentu, dapat mencetuskan penyakit seperti penyumbatan pembuluh darah, kanker, dan kekacauan syaraf. Selain itu, jelantah yang dibuang ke dalam saluran air dapat menyebabkan penyumbatan saluran dan membunuh ekosistem air. Namun demikian, jelantah dapat dimanfaatkan sebagai sumber energi dan bahan baku produk lain yang memiliki nilai ekonomis. Tujuan kegiatan pengabdian kepada masyarakat ini adalah memberikan edukasi kepada kelompok ibu rumah tangga di Gang Salak, Kampung Babakan, Desa Petir, Kabupaten Bogor mengenai bahaya dan manfaat jelantah, mengenalkan teknologi sederhana dalam mengolah jelantah menjadi sumber energi bahan bakar minyak biodiesel. Metode yang dilakukan meliputi 1) Penyebaran kuesioner penjajagan peserta sebelum pelatihan dan kuesioner pascapelatihan untuk melihat dampak pelatihan; 2) Pelatihan; dan 3) Monitoring. Pelatihan pertama, kedua, dan ketiga telah dilaksanakan dengan peserta yang berbeda di lokasi yang sama. Antusias ibu-ibu peserta dan pimpinan lokasi setempat sangat besar dan menginginkan adanya pelatihan untuk peserta yang lebih luas. Dari hasil pelatihan, sebagian besar ibu-ibu peserta pelatihan berhasil meningkatkan ketrampilan dan pengetahuan tentang bahaya dan manfaat jelantah; serta metode pembuatan biodiesel dari jelantah. Pengetahuan ini diharapkan dapat diterapkan dalam kehidupan sehari-hari dengan tidak mengkonsumsi jelantah untuk menggoreng makanan, tetapi dimanfaatkan sebagai bahan baku pembuatan biodiesel.
\end{abstract}

Kata Kunci: edukasi; energi; jelantah; kelompok ibu rumah tangga

\begin{abstract}
Jelantah is the used cooking oil. After being used more than three times for frying, the oil will be oxidized by ambient air, and dangerous free radical compounds are formed. Consuming of jelantah in certain amounts, can trigger diseases such as blockage of blood vessels, cancer and nervous disorders. In addition, jelantah discharged into the drains will cause blockage of drains and kill water ecosystems. However, jelantah can be used as an energy source and other products that have economic value. The purpose of this activity is to provide education for groups of housewives in Babakan Gang Salak, Petir Village, Bogor Regency regarding the dangers and benefits of jelantah, introducing simple technology of biodiesel production. The methods used include questionnaires, training and monitoring. The 1st, 2nd and 3rd trainings were held with different participants in the same location. The the participants' enthusiasm and local site leaders was very high and they wished training for a wider range of participants. The training has been conducted successfully, which was showed that most of the participants could increase their skills and knowledge about the dangers and benefits of jelantah is biodiesel production. This knowledge is supposed to be applied in everyday life by not consuming jelantah for frying food, but it is used as a raw material for biodiesel production.
\end{abstract}

Keywords: education; energy; housewifes group; use cooking oil

\section{PENDAHULUAN}

Minyak goreng sudah merupakan kebutuhan bahan pokok di masyarakat Indonesia. Minyak goreng membuat masakan menjadi lebih enak, sebagai sumber kalori bagi tubuh (Ketaren 
1986). Selain itu, vitamin A, D, E, dan K memerlukan lemak sebagai pelarut agar dapat diserap di dalam tubuh secara efisien, sehingga minyak dalam jumlah yang cukup akan berguna bagi tubuh manusia yang mengkonsumsinya (Vivi 2006). Namun minyak goreng juga merupakan senyawa yang mudah teroksidasi jika terpapar pada lingkungan terbuka atau karena proses pemasakan dan penyimpanan yang salah (Suroso 2013). Pemanasan minyak pada suhu tinggi pada waktu yang lama atau proses pemanasan kemudian didinginkan, lalu dipanaskan kembali secara berulang menyebabkan minyak akan mengalami oksidasi dan terjadi perubahan senyawa menjadi produk akhir aldehid yang reaktif, yaitu Peroxidation of Polyunsaturated Fatty Acids (PUFAs) (Sottero et al. 2019). Jumlah yang seimbang dalam tubuh manusia zat ini merupakan zat anti inflamasi atau dapat mengatasi peradangan (Allice et al. 2021), namun PUFAs dapat teroksidasi oleh senyawa radikal bebas dan dalam jumlah berlebihan merupakan senyawa yang menyebabkan pemicu bahaya dalam tubuh manusia, seperti atheroclerosis (plak pada dinding arteri darah), alzheimer (kerusakan syaraf), dan beberapa jenis kanker (Sottero et al. 2019; Minihane \& Lovegrove 2006). Meila \& Muhartono (2019) menyatakan bahwa mengkonsumsi minyak jelantah dalam jumlah besar dapat menyebabkan munculnya radikal bebas yang dapat membuat kematian sel dan kerusakan sel pada usus halus.

Jelantah merupakan sisa minyak setelah menggoreng makanan. Pada umumnya jelantah masih digunakan kembali untuk menggoreng dan dicampur dengan minyak baru. Pecampuran jelantah dengan minyak baru hanya akan menghasilkan jelantah dan tidak memperbaiki mutu minyak. Pemanasan berulang pada suhu tinggi dan jelantah yang disimpan di dalam wadah terbuka, maka sangat mungkin terjadi oksidasi dan terbentuknya senyawa peroksida berbahaya dalam jumlah besar (Taufik \& Seftiono 2018). Penurunan mutu terjadi pada kandungan gizi jelantah dan gizi makanan yang digoreng menggunakan jelantah. Zahra et al. (2013) membuktikan bahwa terjadi penurunan protein sebesar 30\% pada ayam goreng yang digoreng menggunakan minyak jelantah setelah digunakan selama 25 menit, serta warna makanan semakin gelap setelah digoreng menggunakan jelantah. Selain itu, aroma makanan tercampur dengan masakan lain yang digoreng sebelumnya. Jadi selain mutu minyak dan makanan rusak, tanpa disadari, jelantah tersebut dapat memicu penyakit berbahaya bagi yang mengkonsumsinya dalam jangka waktu lama.

Jelantah yang tidak digunakan untuk menggoreng, selain dibuang ke tempat sampah, seringkali dibuang ke dalam saluran buangan air saat mencuci wadah. Minyak memiliki titik beku yang lebih tinggi dibandingkan dengan air. Sesuai dengan sifat fisik minyak pada suhu $8-11^{\circ} \mathrm{C}$, minyak dapat membeku di dalam saluran air, akibatnya dapat menahan atau mengikat padatan lain yang mungkin masuk dalam saluran, sehingga saluran pembuangan menjadi mampet. Minyak cair yang berada di selokan atau sungai akan mengapung dan menutupi permukaan air, sehingga kadar oksigen di dalam air berkurang, yang dapat menyebabkan terganggunya kehidupan makhluk hidup di dalamnya. Batas ambang pencemaran minyak terhadap biota di dalam air adalah 1mg/L (Rosye et al. 2019). Untuk menghindarinya maka pembuangan minyak ke dalam saluran air harus dicegah dari tingkat yang paling kecil, yaitu rumah tangga.

Permasalahan lain yang muncul adalah ketika jelantah tidak dikonsumsi dan tidak dibuang ke saluran pembuangan adalah menumpuknya jelantah di penampungan dalam rumah, sehingga ibu-ibu memerlukan penyaluran jelantah agar tidak menumpuk di rumah. Pemanfaatan jelantah menjadi sumber energy (biodiesel), sabun, dan lilin diharapkan dapat menjadi solusi dari permasalahan jelantah.

Tujuan kegiatan pengabdian kepada masyarakat ini adalah 1) Memberikan edukasi kepada kelompok ibu rumah tangga di Gang Salak, Kampung Babakan, Desa Petir, Kabupaten Bogor mengenai bahaya dan manfaat jelantah dan 2) Mengenalkan teknologi sederhana dalam mengolah jelantah menjadi sumber energi bahan bakar minyak biodiesel. Sasaran kegiatan ini adalah ibu-ibu rumah tangga di Gang Salak, Kampung Babakan, Desa Petir, Kabupaten Bogor memahami bahaya dan manfaat jelantah, serta mengenalkan teknologi sederhana dalam mengolah jelantah menjadi sumber energi bahan bakar minyak biodiesel. Diharapkan ilmu yang diperoleh dapat dilanjutkan di rumah masingmasing dan dapat menjadi bekal untuk berwirausaha.

\section{METODE PELAKSANAAN KEGIATAN}

\section{Lokasi dan Partisipan}

Partisipan atau mitra adalah kelompok ibuibu rumah tangga yang kesehariannya tinggal di 
rumah mengurus keluarga. Sebagian kecil juga bekerja menjadi pegawai dan buruh di luar rumah atau berwiraswasta dengan berdagang membuka warung kelontong di depan rumah, beternak jangkrik, atau menjadi penjahit. Lokasi mitra berada di Gang Salak, Kampung Babakan, Desa Petir, Kecamatan Dramaga, Kabupaten Bogor. Gang Salak, Kampung Babakan, Desa Petir terletak di Kecamatan Dramaga Kabupaten Bogor (Gambar 1) dan berjarak kira-kira 7 km dari IPB Dramaga. Kondisi alam di lokasi pedesaan ini masih sangat asri, dengan mata air yang sangat jernih dan belum pernah surut.

\section{Metode Pengabdian kepada Masyarakat Program Kemitraan Masyarakat (PPM-PKM)}

Metode PPM-PKM yang digunakan terlihat pada diagram alir Gambar 2 yang meliputi:

- Penjajagan lokasi dan mitra: penentuan lokasi didasarkan pada permintaan salah satu warga yang menginginkan adanya informasi tentang pemanfaatan jelantah menjadi sumber energi biodiesel. Penjajagan dilakukan dengan mendatangi lokasi dan mengurus perijinan terlebih dahulu kepada pimpinan setempat, yaitu Ketua RT 06/02, Kampung Babakan, Gang Salak.

- Penyebaran kuesioner: kegiatan ini bertujuan untuk menggali minat ibu-ibu akan ilmu dan teknologi yang akan disampaikan oleh Tim PPM-PKM. Kuesioner disampaikan secara ter- tulis dan tim PPM berinteraksi langsung dengan ibu-ibu. Kuesioner mencakup pertanyaan sederhana untuk mengetahui kebiasaan ibuibu. Selain itu juga, berupa pertanyaan untuk menggali pengetahuan ibu-ibu tentang jelantah, serta minat, dan kesediaan mengikuti pelatihan.

- Pembuatan reaktor biodiesel dan biodiesel di kampus IPB/laboratorium untuk menyiapkan contoh produk yang akan dihasilkan dalam pelatihan.

- Pelatihan

- Monitoring

- Pembuatan video

- Pelaporan.

\section{HASIL DAN PEMBAHASAN}

\section{Kondisi Mitra}

Ibu-ibu Gang Salak, Kampung Babakan, Desa Petir setiap hari memasak menggunakan minyak goreng. Sisa penggorengan yang berupa jelantah dihasilkan hampir setiap hari dalam jumlah beragam tergantung pada menu masakan yang dibuat pada hari tersebut. Kondisi saat ini, sebagian besar ibu rumah tangga masih menggunakan kembali jelantah untuk menggoreng. Minyak baru ditambahkan dengan jelantah sisa menggoreng hari kemarin. Jelantah yang tersisa, disimpan dalam wadah terbuka (mangkuk atau

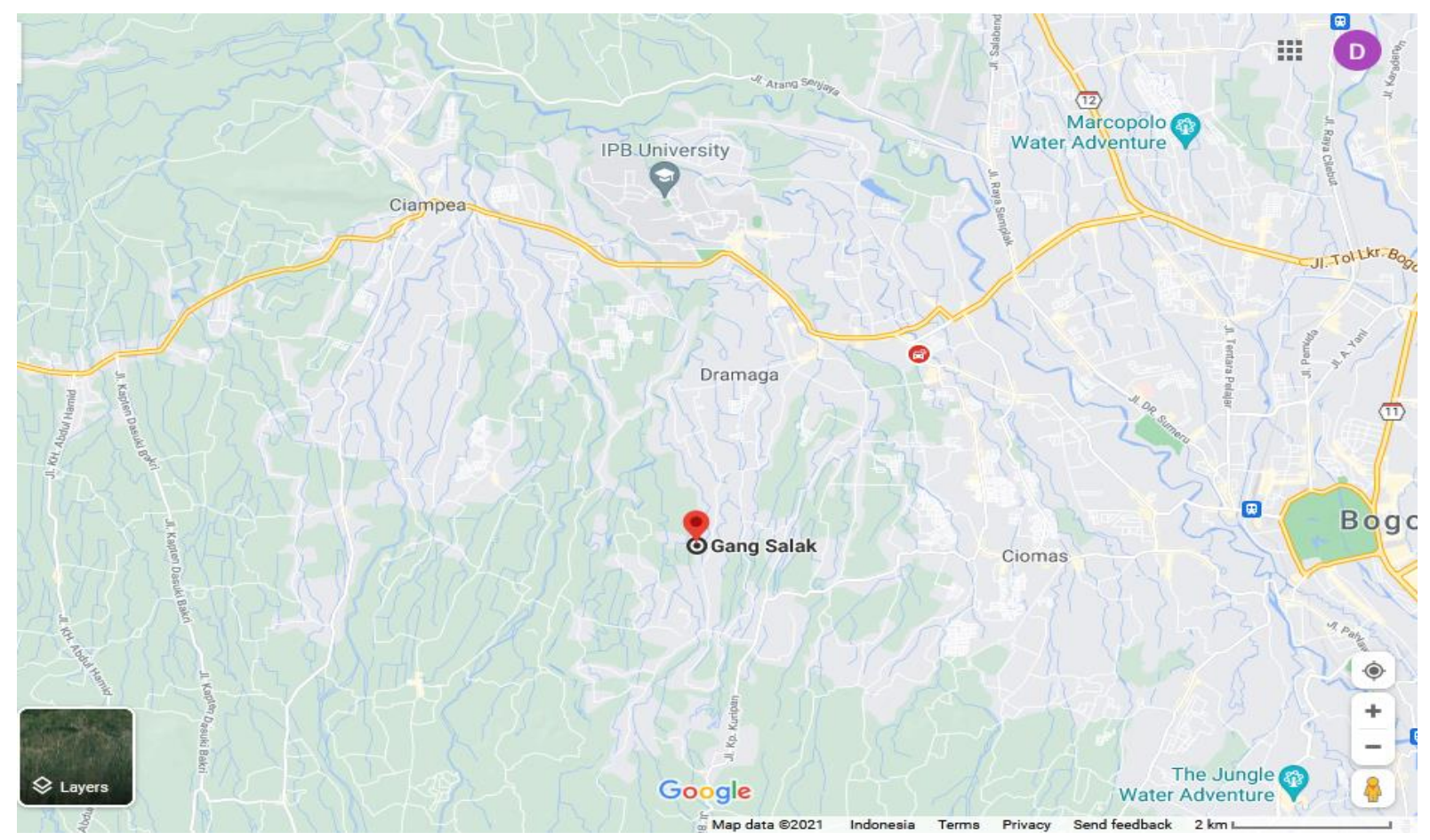

Gambar 1 Lokasi Gang Salak, Kampung Babakan, Desa Petir, Kecamatan Dramaga, Kabupaten Bogor. 


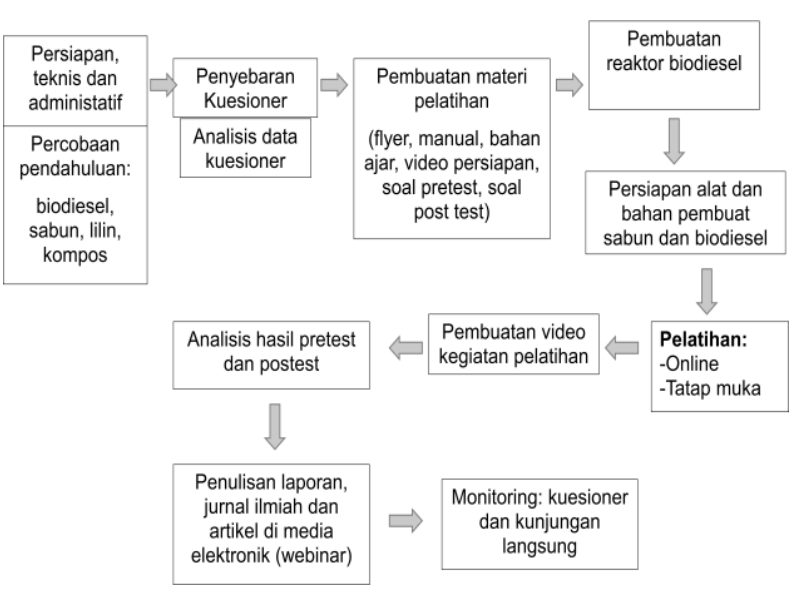

Gambar 2 Diagram alir pelaksanaan kegiatan.

toples), untuk dimasak esok harinya. Sebagian kecil jelantah dibuang ke tempat sampah atau saluran pembuangan atau di pekarangan sekitar.

\section{Hasil Kuesioner Pra-pelatihan}

Kuesioner dibuat bertujuan untuk menggali minat para ibu akan kegiatan pelatihan ini. Berdasarkan hasil kuesioner diperoleh kesimpulan bahwa secara umum, 27 orang dari 32 orang yang mengisi kuesioner menunjukkan minat yang besar untuk mengetahui informasi tentang edukasi jelantah sebagai sumber energi. Para peserta menginginkan pelatihan dilaksanakan dengan tatap muka agar mereka dapat mempraktikkan materi pelatihan secara langsung di lokasi sekitar rumah mereka.

\section{Pembuatan Reaktor Biodiesel}

Reaktor biodiesel yang dibangun merupakan rancangan Ibrahim dan Wulandani (Ibrahim 2017). Reaktor ini (Gambar 3) berbentuk silinder terbuat dari bahan stainlessteel yang dilengkapi dengan motor pengaduk dan pemanas listrik serta alat kontrol putaran motor (inverter) dan alat kontrol suhu (termostat). Kapasitas reaktor adalah $5 \mathrm{~L}$, namun hanya dapat digunakan untuk larutan sebanyak 4 L. Alat digerakkan dengan energi listrik AC dengan daya motor listrik $300 \mathrm{~W}$ untuk memutar pengaduk serta heater sebesar $250 \mathrm{~W}$. Reaktor didudukkan pada rangka besi holow dan dipasangkan panel listrik sebagai mekanisme pengendali.

\section{Pembuatan Biodiesel di Laboratoium}

Pembuatan biodiesel di laboratorium bertujuan untuk dijadikan sample dalam pelatihan. Biodiesel yang dihasilkan pada pelatihan merupakan proses reaksi transestrifikasi dengan metode katalitik. Minyak jelantah direaksikan dengan metanol yang telah dilarutkan dengan

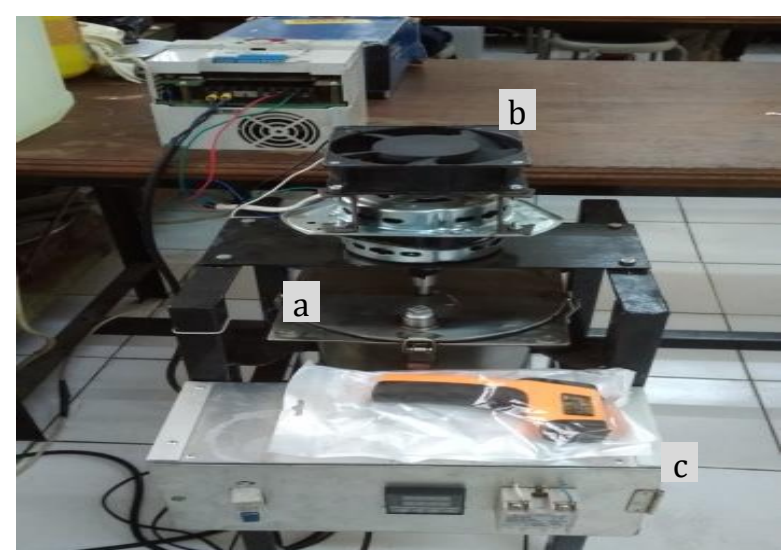

Gambar 3 Reaktor biodiesel: a) Silinder reaktor; b)

Motor pengaduk; dan c) Kotak panel pengontrol.

katalis (KOH) akan membentuk biodiesel dan gliserol (Leung et al. 2010; Fatimura et al. 2016). Biodiesel hasil reaksi dalam reaktor ini belum murni. Proses pemurnian diperlukan jika biodiesel akan digunakan untuk menggerakkan mesin diesel. Proses pemurnian memerlukan tahap perlakuan yang cukup panjang dan sedikit rumit, oleh karenanya, biodiesel yang belum murni ini digunakan sebagai bahan bakar pengganti minyak tanah. Menurut Natalia \& Wasi (2017), karena sifat biodiesel yang mirip dengan solar, maka aman jika digunakan sebagai pengganti minyak tanah.

Dalam rangka memenuhi protokol kesehatan selama pelatihan, maka hand sanitizer dibuat untuk dibagikan kepada peserta dan dipakai selama pelatihan. Pembuatan hand sanitizer telah memenuhi standar WHO (WHO 2006). Bahan yang digunakan untuk pembuatan hand sanitizer terdiri dari alkohol 90\%, gliserol 98\%, $\mathrm{H}_{2} \mathrm{O}_{2}$ (hidrogen peroksida), dan pewangi serta gel lidah buaya untuk melembabkan kulit telapak tangan.

\section{Pelatihan}

Pelatihan dilaksanakan sebanyak tiga kali diikuti oleh 30 peserta, yaitu masing-masing pada tanggal 9, 23, dan 30 Agustus 2020. Setiap pelatihan dibatasi hanya 10 peserta dengan mengikuti protokol kesehatan, sehingga total seluruh peserta adalah 30 orang. Setiap peserta diberikan masker dan hand sanitizer serta menjaga jarak (physical distancing). Lokasi pelaksanaannya berada di ruang kelas SMP PGRI Desa Petir, di saat para murid siswa SMP sedang libur, yaitu pada setiap hari Minggu.

Pre-test dan post-test dilakukan untuk melihat peningkatan kemampuan peserta sebelum dan sesudah pelatihan. Secara umum, ibu-ibu peserta pelatihan lebih menyukai praktik dari- 
pada pengetahuan teoritis. Berdasarkan hasil pre-test dan post-test, pada pelatihan pertama sesi teori, ibu-ibu peserta pelatihan belum berhasil meningkatkan pengetahuan tentang materi yang diberikan secara tertulis. Hal ini dijelaskan oleh data nilai pre-test yang cenderung mengalami penurunan dibandingkan nilai post-test-nya (Gambar 4). Penyebabnya adalah beberapa ibu-ibu agak kesulitan membaca (terbata-bata dan rabun), ibu-ibu tidak terbiasa mengerjakan soal tes tertulis, soal tes terlalu teoritis, dan penggunaan istilah dalam soal tes yang sangat asing cukup menyulitkan ibu-ibu. Ada peserta yang tidak mengerjakan post-test karena ijin pulang terlebih dahulu, disebabkan putranya yang balita rewel. Latar belakang pendidikan ibu-ibu rata-rata di tingkat sekolah dasar dan sangat beragam, namun dari segi praktiknya, ibu-ibu terlihat sangat trampil dan cepat mengerti.

Hasil pada pelatihan pertama menjadi bahan evaluasi untuk pelatihan berikutnya. Soal pre-test dan post-test disesuaikan dengan tingkat pengetahuan ibu-ibu dan lebih banyak menanyakan hal praktis dibandingkan dengan teoritis. Hasil evaluasi pre-test dan post-test pada pelatihan kedua dan ketiga menunjukkan pe- ningkatan pengetahuan yang signifikan yaitu masing-masing 32 dan $48 \%$ dan nilai rata-rata yang lebih tinggi dibandingkan hasil pelatihan pertama (Gambar 5 dan 6).

Pada praktik pembuatan biodiesel, ibu-ibu terlihat sudah trampil dan cepat memahami penjelasan yang diberikan. Mereka dapat menimbang, mengukur volume, mencampur bahan tahap demi tahap secara baik serta memahami sifat-sifat dan bahaya dari bahan-bahan yang digunakan untuk percobaan (Gambar 7 dan 8). Meskipun proses pembuatan biodiesel cukup sederhana, namun karena menggunakan reaktor dan peralatan pengukur elektronik, ibu-ibu masih perlu bantuan teknisi dalam mengoperasikannya. Biodiesel yang dihasilkan memiliki karakteristik yang baik (Gambar 9). Biodiesel yang dihasilkan belum murni, sehingga hanya dapat diujicoba sebagai bahan bakar kompor semawar. Hasil pembakaran biodiesel pada kompor semawar memiliki kualitas api yang biru dan dapat mendidihkan $1 \mathrm{~L}$ air dalam waktu 7 menit (Gambar 10).

\section{Monitoring}

Pada akhir bulan Oktober 2020 dilakukan penyebaran kuesioner dan kunjungan langsung

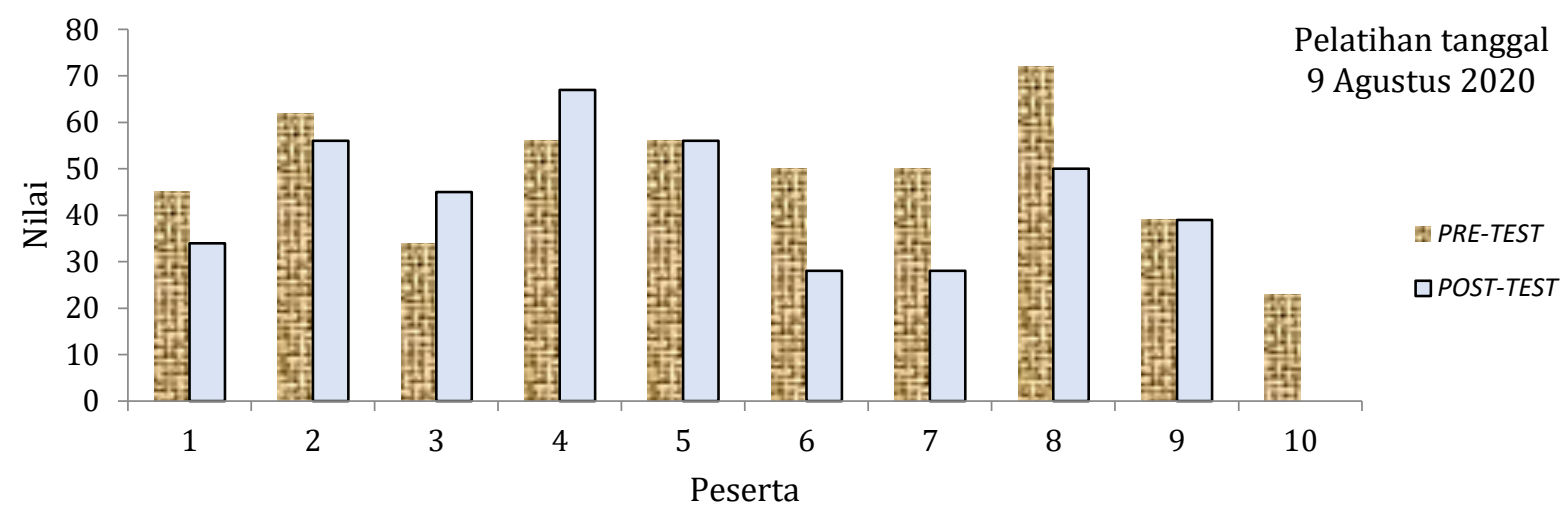

Gambar 4 Hasil nilai pre-test dan post-test pelatihan pertama, tanggal 9 Agustus 2020.

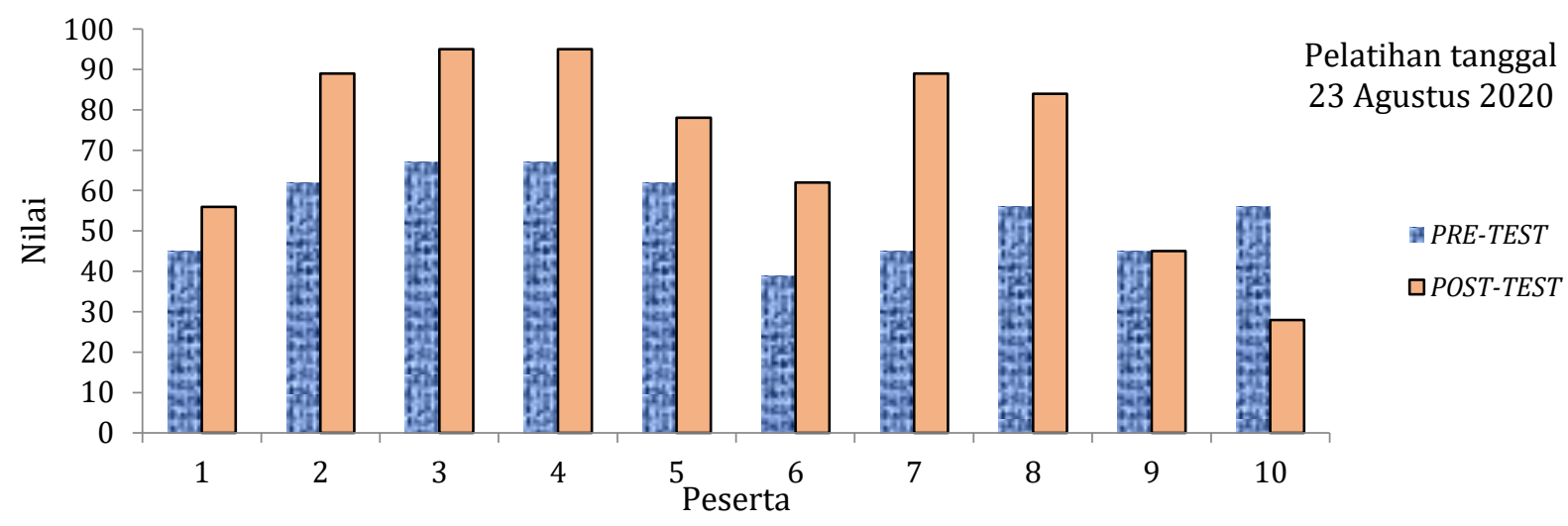

Gambar 5 Hasil nilai pre-test dan post-test pelatihan kedua, tanggal 23 Agustus 2020. 


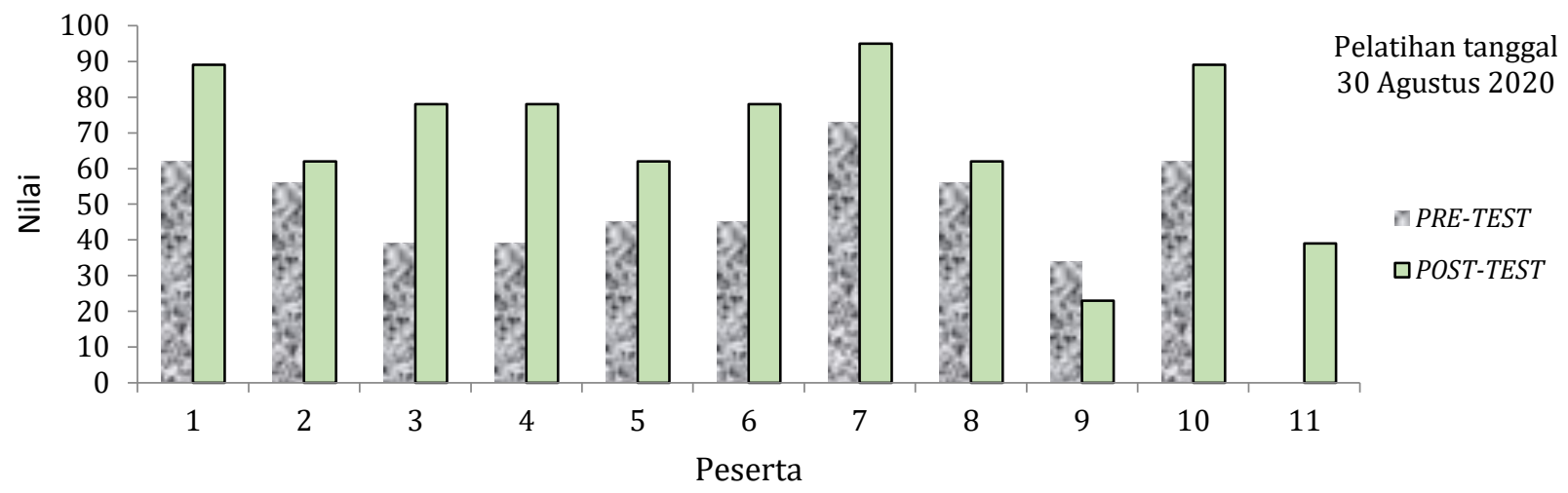

Gambar 6 Hasil nilai pre-test dan post-test pelatihan ketiga, tanggal 30 Agustus 2020

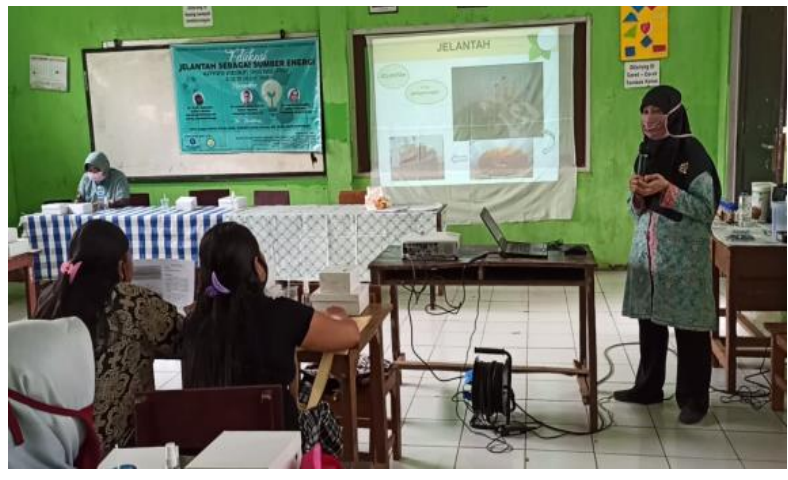

a

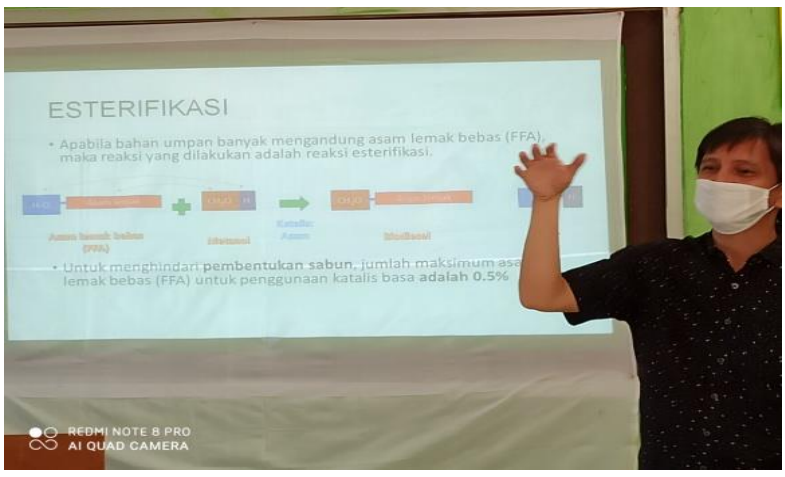

b

Gambar 7 a) Pemberian materi jelantah dan b) Pemberian materi biodiesel.

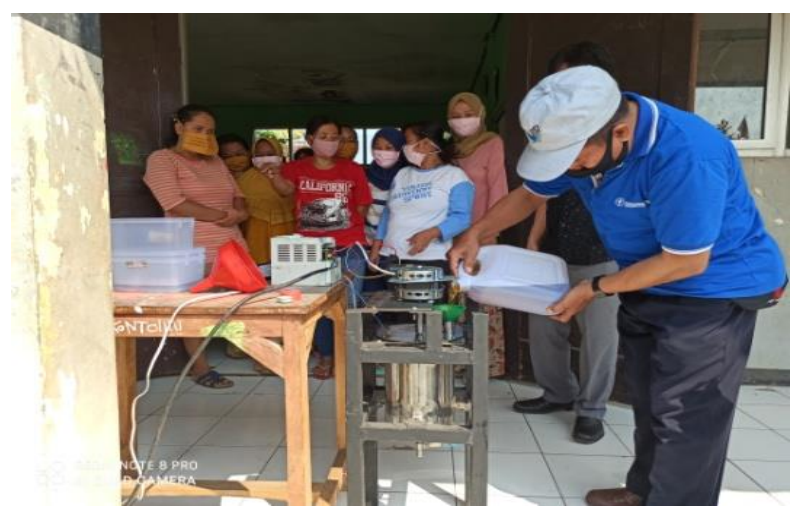

a

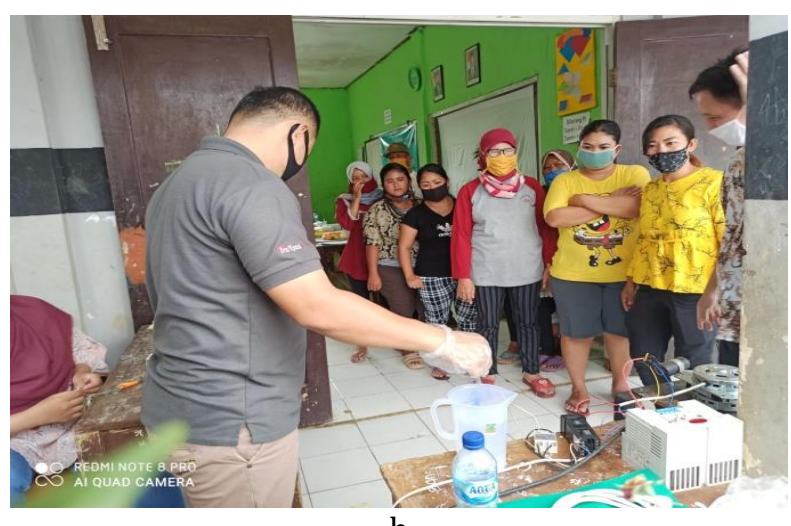

b

Gambar 8 Proses pembuatan biodiesel: a) Jelantah dimasukkan ke dalam reaktor dan b) Pembuatan larutan metanolik.

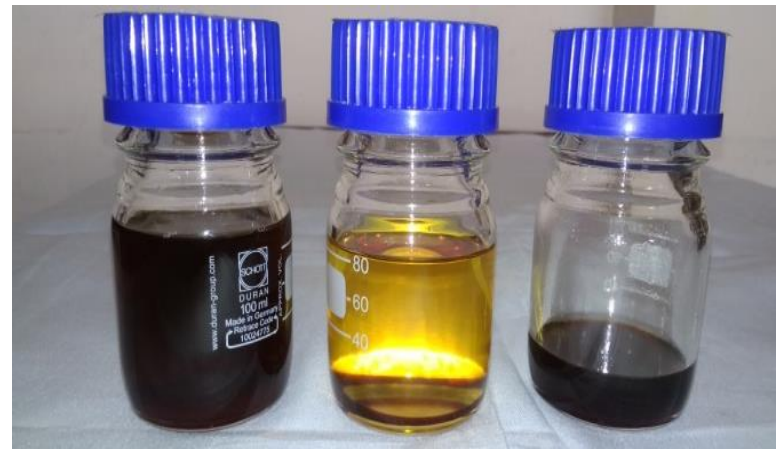

Gambar 9 Produk biodiesel yang dihasilkan: a) Jelatah; b) Biodiesel; dan c) Gliserol.

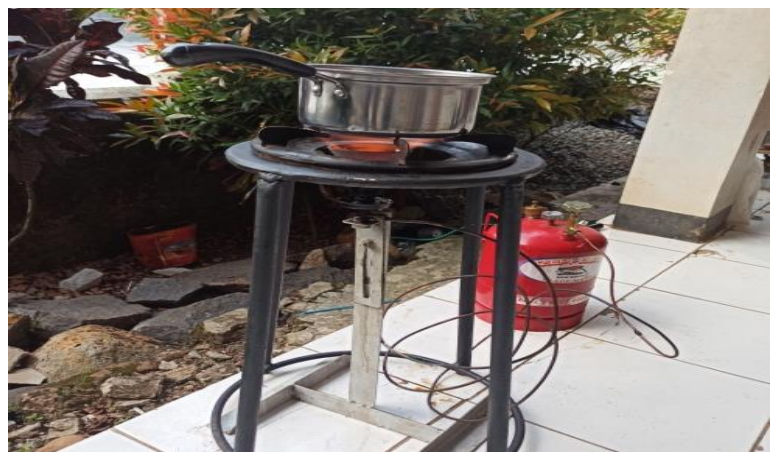

Gambar 10 Ujicoba biodiesel sebagai bahan bakar kompor semawar. 
untuk melihat dampak dari pelatihan yang telah dilaksanakan pada bulan Agustus 2020. Hasil kuesioner menunjukkan 70\% ibu-ibu peserta pelatihan mulai mencoba mengumpulkan jelantah, tidak menggunakannya lagi untuk menggoreng. Hasil jelantah masih sangat sedikit, dalam waktu 1 bulan, rata-rata baru memperoleh jelantah sebanyak $200 \mathrm{~mL}$ per rumah tangga, sehingga belum digunakan untuk mempraktikkan pengetahuan hasil pelatihannya. Ibu-ibu peserta diharapkan dapat mengajak kepada ibu-ibu lain tetangga terdekat agar tidak mengkonsumsi jelantah atau tidak membuang jelantah di sembarang tempat, tetapi mencoba mengumpulkannya dalam botol plastik. Selanjutnya jelantah terkumpul dapat digunakan untuk membuat biodiesel.

\section{SIMPULAN}

Kegiatan Pengabdian kepada Masyarakat dalam rangka memberikan pengetahuan tentang uelantah sebagai sumber energi kepada ibu-ibu di Gang Salak, Kampung Babakan, Desa Petir telah meningkatkan pengetahuan sebagian ibuibu rumah tangga yang telah mengikuti pelatihan tentang penggunaan jelantah (bahaya dan manfaat jelantah), sehingga tidak lagi menggunakan jelantah untuk menggoreng; tetapi akan memanfaatkan jelantah, terutama untuk membuat sabun dan lilin yang memiliki teknologi lebih sederhana dibandingkan dengan pembuatan biodiesel. Pelatihan dan pendampingan untuk kegiatan pemanfaatan jelantah yang lebih produktif atau skala komersial, diperlukan pada masa yang akan datang untuk menciptakan wirausaha kecil skala rumah tangga dan membantu meningkatkan taraf hidup masyarakat.

\section{UCAPAN TERIMA KASIH}

Penulis menyampaikan terima kasih kepada Kemenristek/Badan Riset dan Inovasi Nasional yang telah membiayai pelaksanaan kegiatan Pengabdian kepada Masyarakat, melalui dana hibah Program Kemitran Masyarakat (Tahun 2020), hingga pelaksanaan kegiatan berhasil dengan baik. Terima kasih juga disampaikan kepada Kepala SMP PGRI, Desa Petir, Kabupaten Bogor, yang telah memberikan ijin untuk mempergunakan lokasi sekolah sebagai tempat dilaksanakannya pelatihan.

\section{DAFTAR PUSTAKA}

Allice SCV, Rayana LG, Maria EAT,Inês CG, Ana PMMC, Beatriz da CAA, Sabrina AL, Luiz CMV, Giovana RT. 2021. Supplementation of polyunsaturated fatty acids (PUFAs) and aerobic exercise improve functioning, morphology, and redox balance in prostate obese rats. Nature Portofolio/Scientific Reports. 11: 62-82. https://doi.org/10.1038/s41598-02185337-9

Fatimura M, Daryanti, Santi. 2016. Pembuatan biodiesel dari minyak jelantah bekas rumah makan dengan variasi penambahan katalis $\mathrm{KOH}$ pada proses transesterifikasi. Jurnal Redoks. 1(2): 35-43. https://doi.org/10.31851/ redoks.v1i2.2027

Ibrahim AZ. 2017. Rancang bangun reaktor dengan menggunakan helical screw agitator dan baffle untuk produksi biodiesel secara batch. [Skripsi]. Bogor (ID): Institut Pertanian Bogor.

Ketaren S. 1986. Pengantar Teknologi minyak dan lemak pangan. Jakarta (ID): UI Press.

Leung DYC, Wu X, Leung MKH. 2010. A review on biodiesel production using catalyzed transesterification. Applied Energi. 87(4): 1083-1095. https://doi.org/10.1016/ j.apenergy.2009.10.006

Meila M, Muhartono. 2019. Konsumsi minyak jelantah dan pengaruhnya terhadap kesehatan. Majority (Medical Journal of Lampung Univerity). 8(2): 259-264.

Minihane AM, Lovegrove JA. 2006. Health benefits of polyunsaturated fatty acids (PUFAs). In: Improving the Fat Content of Foods. Woodhead Publishing Series in Food Science, Technology and Nutrition. https://doi.org/ 10.1533/9781845691073.1.107

Natalia ES, Wasi SWP. 2017. Pengolahan minyak goreng bekas (jelantah) sebagai pengganti bahan bakar minyak tanah (biofuel) bagi pedagang gorengan di sekitar FMIPA UNNES. Rekayasa-Jurnal Penerapan Teknologi dan Pembelajaran. 15(2): 89-95. 
Rosye HRT, Baigo H, Alianto. 2019. Konsentrasi surfaktan dan minyak di Perairan Depapre, Kabupaten Jayapura, Popinsi Papua. Buletin Oseanografi Marina. 8(1): 49-54. https://doi. org/10.14710/buloma.v8i1.22264

Sottero B, Leonarduzzi G, Testa G, Gargiulo S, Poli G, Biasi F. 2019. Lipid Oxidation Derived Aldehydes and Oxysterols Between Health and Disease. European Journal of Lipid Science and Technology. 121(1): 1-16. https://doi.org/ 10.1002/ejlt.201700047

Suroso AS. 2013. Kualitas minyak goreng habis pakai ditinjau dari bilangan peroksida, bilangan asam, dan kadar air. Jurnal Kefarmasian Indonesia. 3(2): 77-88.

Taufik M, Seftiono H. 2018. Karakterisitik fisik dan kimia minyak goreng sawit hasil proses penggorengan dengan metode deep-fat frying. Jurnal Teknologi. 10(2): 123-129.

Vivi T. 2006. Macam-macam vitamin dalam tubuh manusia dan fungsinya. Jurnal Kesehatan Masyarakat. I(1): 40-47.

[WHO] World Health Organization. 2006. WHO guidelines on hand hygiene in health care (advanced draft)- World alliance for patient safety-Global patient safety challenge (2005-2006)- clean care is safer care.

Zahra SL, Dwiloka B, Mulyani S. 2013. Pengaruh penggunaan minyak goreng berulang terhadap perubahan nilai gizi dan mutu hedonik pada ayam goreng. Animal Agriculture Journal. 2(1): 253-260. 